https://doi.org/10.31516/2410-5333.054.13

УДК 338.487:659.126(477)(045)

S. S. Rostovtsev, Candidate of Sciences in Social Communications, Senior Lecturer, Kharkiv State Academy of Culture, Kharkiv

rostovtsev.sergey@gmail.com

https://orcid.org/0000-0003-4437-9190

\title{
BRANDING OF UKRAINE AS A TOURIST DESTINATION
}

This paper is presents the ways of the development of Ukrainian touristic brand developing. Particular attention is given to the core values of country branding and identification of the key aspects of country positioning. The study shows the importance of presenting Ukraine abroad by taking part in international exhibitions, competitions, championships and other events. Special attention is also paid to the importance of online presence and the necessity of creating high quality tourism website. The paper describes components which are important to perform SEO so that the website could reach the first position in search results.

Keywords: tourism destination, branding of Ukraine, Search Engine Optimization, presenting of Ukraine abroad, destination brand.

С. С. Ростовцев, кандидат наук з соціальних комунікацій, старший викладач, Харківська державна академія культури, м. Харків

\section{БРЕНДИНГ УКРАЇНИ ЯК ТУРИСТИЧНОГО НАПРЯМУ}

Актуальність. Активне залучення іноземних туристів на територію України передбачає й наявність впізнаваного туристичного бренда країни, що зумовлює дослідження способів його створення та розвитку.

Мета статті - запропонувати способи створення бренда України як туристичної дестинації.

Методологія. У дослідженні використано методи опису, зіставлення та узагальнення.

Результати. Згідно з дослідженням, в умовах розвитку інформаційнокомунікаційних технологій необхідною умовою залучення іноземних туристів на територію України є формування бренда дестинації, який дозволить країні виокремитися 3-поміж конкурентів за допомогою створення унікального імені та позиціювання для цільової аудиторії. Водночас зазначається, що сьогодні більшість учасників ринку, обираючи туристичні напрямки, надає переваги передусім інформації, отриманої з Інтернету. Утім представленість України на міжнародному ринку в онлайн-середовищі недостатня, a Інтернет як рекламний майданчик потребує досконалішого вивчення.

Новизна. Уперше пропонується практичний підхід до створення бренда України з орієнтацією на онлайн-середовище.

Практичне значення. Рекомендації, наведені в дослідженні, можуть використати відповідні особи в процесі формування стратегії розвитку туристичного бренда України та її реалізації.

Висновки: Створення туристичного бренда України має передбачати: 1) з'ясування основних цінностей брендингу країни; 2) визначення ключових аспектів позиціювання країни; 3) створення та поширення атрибутів 
бренда, таких як логотип і слоган; 4) представлення країни за кордоном на міжнародних виставках, конкурсах, чемпіонатах та інших заходах; 5) створення експертної групи, яка відповідатиме за стратегічні та технічні питання брендингу України; 6) створення високоякісного туристичного веб-сайта; 7) здійснення пошукової оптимізації для досягнення веб-сайтом перших позицій в результатах пошуку.

Ключові слова: брендинг України, туристична дестинація, пошукова оптимізація, презентація України за кордоном, бренд території.

C. C. Ростовцев, кандидат наук по социальным коммуникациям, старший преподаватель, Харьковская государственная академия культуры, г. Харьков

\section{БРЕНДИНГ УКРАИНЫ КАК ТУРИСТИЧЕСКОГО НАПРАВЛЕНИЯ}

Показано, что в условиях развития информационно-коммуникационных технологий необходимым условием привлечения иностранных туристов на территорию Украины является формирование бренда дестинации, который позволит стране выделиться среди конкурентов путем создания уникального имени и позиционирования в сознании целевой аудитории. Вместе с тем, отмечается, что сегодня большинство участников рынка, выбирая туристические направления, руководствуется в первую очередь информацией, полученной с Интернета. В результате предложен ряд мероприятий по созданию туристического бренда Украины.

Ключевые слова: брендинг Украины, туристическая дестинация, поисковая оптимизация, презентация Украины за рубежом, бренд территории.

Problem statement. The development of information and communication technologies in recent years has led to the emergence of new models of relationships in the social and economic life. If we talk about tourist destinations as one of the objects of influence of socio-economic changes, the current situation requires both tourism business representatives and state authorities to be familiar with the diversity of new technologies and marketing tools and quickly adapt their activities in accordance with modern requirements. Special attention, however, should be given to the branding of a destination that will distinguish itself from competitors by creating a unique name and positioning in the minds of the target audience.

The state authorities of Ukraine have recently carried out a number of actions oriented on popularizing the country around the world - in particular brand attributes of the country have been developed with recommendations on their use. At the same time, it should be noted that most people these days are guided primarily by information from the Internet, when they choose tourist destinations. However, the representation of Ukraine as tourist destination in online environment remains at an insufficient level, and the Internet as an advertising space requires a more thorough study. 
Research publications. Branding of territories as a scientific challenge has been widely covered in the works of both Ukrainian and foreign experts. Specific features of the promotion of certain regions and cities of Ukraine were studied by such scholars as O. Soskin, O. Olefirenko, M. Karpishchenko, V. Yermachenko, I. Smirnov, S. Matusyak and others. Such researches as O. Zozulov, S. Sholudchenko, N. Vladchenko studied the structural components of the territory brand. Issues of constructing a strategy for promoting the tourist brand of the country were studied by E. Blinov, O. Muzychenko-Kozlov, O. Bilovodska and others.

However, it is important to understand that the role of the Internet and search optimization, as tools of destinations promotion, are not sufficiently studied.

The main material. The choice of tourism destination is a significant lifestyle indicator for today's consumers and the places where they choose to spend their time should have emotional appeal, high conversational capital and celebrity value. The World Tourism Organization confirms this view, suggesting that tourism destinations will be considered by customers as fashion accessories in the twenty-first century. Indeed, as style symbols, destinations can offer similar consumer benefits to highly branded lifestyle items. These are used to communicate statements and group memberships, as vacation trips are expressive devices communicating messages about identity, lifestyle and status. Traveling for leisure is increasingly permeating the discourse of everyday life, but remains a highly involving experience, extensively planned, excitedly anticipated and fondly remembered.

Like manufacturers' brands, place brands evoke certain values, qualifications and emotional triggers in the consumer's mind about the likely values of any product that comes from that place. A place brand can behave just like a manufacturer's brand, providing trust, a guarantee of quality, which promotes the entry of its new "sub-brands" on the market.

The American Marketing Association (2018) defines a brand as a "name, term, sign, symbol, or design, or a combination of them intended to identify the goods and services of one seller or group of sellers and to differentiate them from those of competition". However, launching a global place brand requires an objectivity - the ability of managers to see the places as others do, and to accept that this is, at least in commercial terms, more important than the way they see themselves. It requires government support and constant investment in the place brand itself, which in turn requires commitment, collaboration and effective synergy among the main communicators of the country's image in the global media: usually the tourist board, the airline and the major food producers, because these are the routes by which the national brand is most commonly created and exported. 
It is also important to remember that branding a country is not the same thing as promoting tourism. The promotion of tourism obviously occupies more common ground with nation-branding than any other aspect of a country's external affairs, but it is merely a part of the whole. Although the economies of more and more places do depend on tourism, other factors may be equally important, such as stimulating inward investment and aid, encouraging both skilled and unskilled workers to immigrate, promoting the country's branded and unbranded exports internationally, increasing the international business of the national airline, facilitating the process of integration into political and commercial organizations such as the European Union or the World Tourism Organization, and a wide range of other interests (Morgan, Pritchard, \& Pride, 2015).

A country's image results from its geography, history, ideas, art and music, famous citizens and other features. The entertainment industry and the media play a particularly important role in shaping people's perceptions of places, especially those viewed negatively. Not only are product categories such as perfumes, electronics, precision instruments, wines, cars and software strongly identified with certain places, but so also are societal ills such as AIDS epidemics, political riots, civil rights violations, attacks on the environment, racial conflict, economic turmoil, poverty and violent crime. All of these have been repeatedly and strongly associated with certain locales. Of course, different people and groups are likely to hold different stereotypes of nations since the mental phenomenon is inherently subjective. However, sometimes they are widespread and pervasive across elements of the same group; they are social cognitions, mental representations shared by members of a given society (Grundey, Toluba, \& Brukiene, 2006).

Strategic place marketing concerns the enhancement of a country's position in the global marketplace. It requires understanding the environmental forces that may affect marketability, that is, the strengths and weaknesses of the country to compete with others, such as the size of domestic market, access to regional trade areas, education of the population, tax incentives, skilled labour, cost of labour, security and others. It also entails monitoring the external environment, that is, a dynamic understanding of opportunities and threats, as well as the competitive forces in the environment. The process must involve government, citizens and businesses, all with a shared vision. It requires setting and delivering the incentives and managing the factors that may affect place buyers' decisions, including image, attractions, infrastructure and people. The following subsections will deal with different tasks of country brand management, namely, managing the image, attracting tourists, attracting factories and companies, and seeking new market opportunities. 
Confronting a negative image can be a difficult task. There is no control over environmental factors that may keep tourists and investors away, such as natural disasters, political turmoil and economic downturns. Even more difficult can be controlling how the media and the press disseminate a country's problem, often creating or perpetuating stereotypes. And to improve a country's image, it may be easier to create new positive associations than trying to refute old ones.

For country branding the following strategic management approach is required:

1. To carry out a SWOT analysis to determine its key strengths, weaknesses, opportunities and threats.

2. To choose some industries, personalities, natural landmarks and historical events that could provide a basis for strong branding and storytelling.

3. To develop a concept that would cover and be consistent with all of its separate branding activities. (For example a country of pleasure, quality, security, honesty, progress or other concepts).

4. To allocate sufficient funds to each branding activity which is to have a large impact.

5. To create export controls to make sure that every exported product is reliable and delivers the promised level of performance.

A destination brand can be developed in a variety of ways, most obviously in advertising, through direct marketing, personal selling, on websites and in brochures, but also through public and media relations, and through the cooperation of destination marketing organizations (DMOs) with journalists, event organizers and film-makers. Moreover, place promotion, defined as 'the conscious use of publicity and marketing to communicate selective images of specific geographic localities or areas to a target audience', not only involves advertising and publicity, but also encompasses "flagship" developments and events in the arts, media, leisure, heritage, retailing or sports industries (Gold, \& Ward, 1994, p. 2).

According to study results on how Ukraine is perceived abroad, conducted with the support of the British government, the three most popular associations with Ukraine are "corruption", "revolution" and "war" (Banda agency, 2018).

People, who have never been to Ukraine, see Ukrainians as closed, aggressive and intolerant. This image is shaped largely from what they see and hear in the news. With such a reputation it is difficult to attract investment and tourists to the country. However, those who have visited country at least once, change their minds and point out the hospitality of Ukrainians, wonderful landscapes, culture and architecture.

In order to change the image of Ukraine and convince foreigners to visit it, it is vital to have a new brand that will show Ukraine as an open and 
modern country. The previous country's tourism brand identity "Ukraine: It's all about U" didn't find an extensive use in promotion activities despite the detailed description of the brandbook. In 2018 the large international marketing campaign of the Ukrainian government "Ukraine Now" started. Its goal is to form a new brand of Ukraine in the world, to attract investments into the country and to improve the tourism potential. The commission of 27 experts took part in preparation of this campaign. Their task was to collect data and materials for brand creation that will demonstrate the attractiveness of Ukraine for tourism, cultural interaction and business.

As a result, the Cabinet of Ministers of Ukraine approved a single brand "Ukraine Now" that was suggested by the Ukrainian agency "The Banda" in the framework of work of the Commission for the issues of Ukraine's promotion within the Ministry of Information Policy of Ukraine and on the proposals of British partners. At present has been created an adaptable for different needs brand's logo and a brandbook with explanations and recommendations on its usage.

Moreover, the Ministry of Information Policy of Ukraine (2018) puts a number of measures into effect on Ukraine promotion. For example in 2018 the new brand was presented at the American Chamber of Commerce in London (Great Britain), at the presentation of government reforms in Copenhagen (Denmark), New York (USA) and numerous public events on all topics and areas of focus.

However, establishing the core values of the destination and its brand and developing the brand identity are only a small part of successful country brand positioning. One way to present the country abroad is its participation in international exhibitions, competitions, championships and other events. To maximize the country's brand awareness and attract new foreign tourists, such tools as offline advertising, including videos, should be used. At the same time, when we talk about advertising, it is important to define the target audience and promotional materials.

According to the fact that the climate and natural resources of Ukraine are of a little difference with neighboring states and the most of European countries it should be assumed that these territories can't become wide tourist's providers in terms of traditional tourism interests. Therefore, the efforts must be focused on more distant countries for which Ukraine is seen as an exotic country such as Morocco, Iran etc.

As for the promotional materials, it should be a concentration of topical information aimed at presentation of Ukrainian's nature, ethnic cuisine, cultural characteristics, business opportunities etc, with brand attributes usage. For example, the project "Ukrainer" (2018) - an expedition the aim of which is to discover various regions of Ukraine - suggests a number of 
high-quality videos that show the beauty of Ukrainian nature and which can be used for advertising purposes.

On a par with the participation in international exhibitions, competitions and other offline activities, the Internet plays a crucial role in promoting the country. The vast majority of travelers make their decision about travel destination based on the information from the Internet, using such search queries as "travel to Ukraine", "what to see in Ukraine", "places to visit in Ukraine" etc.

According to these queries, we get links to the websites "Travel to Ukraine", which is called as the official website and guide for Ukraine, but which has an unattractive interface design, visible problems of some images and icons display, mobile unfriendliness and some others; "Lonely Planet", which can serve as an authoritative source for foreigners, but presents a limited amount of information and does not reveal the features of Ukraine to the full extent, and a number of less relevant resources. The newly created project "Ukrainer" has high-quality content and may be of interest to travelers, but it is limited on describing places and people only, without providing additional tourist information and it is not visible in the top of search results for English-speaking queries.

Thus, there is a lack of single web resource, which will allow to meet the information needs of travelers in full. To solve this problem the two stepprocess is needed: 1) to create a well-designed, attractive and informative tourist web site; 2) to optimize this website and reach the top positions in search results on various queries.

As for the website structure, it must include such elements: 1) Logo (Ukraine Now); 2) Header 1 with buttons "About Ukraine", "Media Center" (Photos, Videos, Articles), "Contact Us", links on social media accounts, "Search", "Language Preference", "Favorites" and "Visit Planner"; 3) Header 2: "Where to go", "What to do", "Experience", "Stories", "Events" and "Visit Planner"; 4) An image slider with high resolution photos; 5) Website body which has such blocks one under another: "Top stories", "Where to go", "Hot attractions" on an interactive map, "What to do", "Experiences", "Stories shared by locals and travels"; 6) Footer 1: "Site Map", "Upcoming events", "Latest stories", "Find us on Social media", "Subscribe to our news"; 7) Footer 2: Links for downloading apps. Such structure will give an opportunity to present the most relevant information in the most compact way.

Considering that search engines generate the most traffic to the websites, comparing to social media and other types of communicative tools, the next step after creating a user-friendly, well-structured and properly designed touristic website of a country is to increase its visibility in organic (non-paid) search engine results and improve rankings, so that potential tourists could reach according to their search query and satisfy their information needs. 
To increase the website visibility, such marketing activity as Search Engine Optimization (SEO) should be used, which is aimed at making website easy for both users and search engine robots to understand. The SEO-process includes a number of following stages (Moz, 2018):

1) Engine-friendly design and development that must be provided by programmers, information architects and designers. This aspect includes: providing alt text for images; supplementing search boxes with navigation and crawlable links; Flash or Java plug-ins with text on the page; providing a transcript for video and audio content if the words and phrases used are meant to be indexed by the engines.

2) Keywords usage and targeting. Keywords are the building blocks of language and search and are the basis for information retrieval (including web-based search engines like Google). The keyword phrases mentioned above should be used: in the beginning of the title tag; once prominently near the top of the page; at least two or three times, including variations, in the body copy on the page; once in the alt attribute of an image on the page; in the URL; in the meta description tag.

3) The title element of a page usage, which is meant to be an accurate, concise description of a page's content and is critical to both user experience and search engine optimization.

4) Meta tags usage. The Meta Robots tag can be used to control search engine crawler activity (for all of the major engines) on a per-page level. The meta description tag exists as a short description of a page's content. Search engines do not use the keywords or phrases in this tag for rankings, but meta descriptions are the primary source for the snippet of text displayed beneath a listing in the results. Also such metatags as Meta Keywords, Meta Content-type etc are used.

5) Avoiding canonical and duplicate versions of content.

6) Usage of snippets, which help easily identify the type of content for search engines.

7) Providing easy to use, navigate and understand website, which is professionally designed and accessible to modern browsers with high quality, legitimate and credible content.

8) Links building. There are three basic types of links: "Natural" editorial links that are given naturally by sites and pages that want to link to the specific content; Manual "outreach" links are created by emailing bloggers for links, submitting sites to directories, or paying for listings of any kind; Selfcreated, non-editorial links include the opportunity to create links through guest book signings, forum signatures, blog comments, or user profiles.

Generally, these steps do not require significant financial expenditures, but presuppose the presence of a specialist responsible for the development 
and support of the website, which is also meant to be a SEO-specialist, copywriter and designer, as well as to be aware of the website idea, its orientation, specifics and goals.

Conclusion. Thus, one of the conditions for creating a destination brand is the constant usage of all the brand attributes. However, for most brands it is sufficient to use two or three of them, and they must be in harmony with each other, fit into the overall brand's unique system, take into account consumer preferences and expectations. For Ukraine the process of tourism brand building consists of several important steps: 1) To find out the core values of country branding; 2) To identify the key aspects of country positioning; 3) To create and overspread the brand attributes such as logo and slogan; 4) To present the country abroad by taking part in international exhibitions, competitions, championships and other events; 5) To form an expert group which will be responsible for strategic and technical issues of Ukraine branding; 6) To create a high quality website; 7) To perform SEO so that the website could reach the first position in search results.

\section{References}

American Marketing Assosiation. (2018). American Marketing Assosiation. Retrieved from https://www.ama.org/ [In English].

Banda Agency. (2018). Banda Agency. Retrieved from http://banda.agency/ ukrainenow/ [In Ukrainian].

Brukiene, J., Grundey, D., \& Toluba, B. (2006). Country Image as a Marketing Tool for Fostering Innovation and Entrepreneurship. Economics and Competition Policy, p. 25-42.

Gold, J., Ward, S. (1994). Place promotion: The use of publicity and marketing to sell towns and regions. John Wiley and Sons, p. 228.

Ministry of Information Policy of Ukraine. (2018). Ministry of Information Policy of Ukraine. Retrieved from https://mip.gov.ua/en/ [In English].

Morgan, N., Pritchard, A., \& Pride, R. (2015). Destination Brands (3 ed.). London: Routledge [In English].

The Beginners Guide to SEO. (2018). MOZ. Retrieved from https://moz.com/ beginners-guide-to-seo [In English].

Ukraïner. (2018). Ukraïner. Retrieved from https://ukrainer.net/ [In Ukrainian].

Надійшла до редколегії 17.01.2019 р. 